\title{
KARAKTER KEPEMIMPINAN NABI MUSA AS DALAM AL-QUR'AN
}

\author{
Ahmad Zain Sarnoto ${ }^{1}$, Hidayatullah ${ }^{2}$ \\ Institut PTIQ Jakarta, \\ Mahasiswa Pascasarjana Institut PTIQ Jakarta \\ Email:ahmadzain@ptiq.ac.id, hidayathamim@gmail.com
}

\begin{abstract}
ABSTRAK
Karakter pemimpin pada kisah Nabi Musa AS mencakup sejumlah karakter utama, seperti sabar, visioner, kompeten, integritas, pembaharu, solutif, religius, kredibel, cerdas, pandai bekerja sama, memiliki tekad yang kuat, informan, pembelajar dan tawadhu'.

Penelitian ini memiliki perbedaan pendapat dengan: 1) Niccolo Machiavelli (L. 1469 M) yang memisahkan antara etika dan politik dalam melaksanakan dan menerapkan nilai-nilai kepemimpinannya. Pemerintah sebagai pemangku institusi kepemimpinan nasional harus menjalankan tugas-tugas negara dengan baik sesuai dengan nilai-nilai kepribadian bangsa sebagaimana yang tertuang dalam Undang-undang Dasar (UUD) 1945 dan Pancasila, 2) Alexander Agung (L. 340 SM) yang berambisius menumpuk harta kekayaan, bertindak brutal, memerintahkan pengikutnya untuk menyembah dirinya dan tidak segan-segan membantai siapa saja yang menentang kekuasaannya. Pemerintah dan semua pemangku jabatan sejatinya hidup dengan karakter kesederhanaan, santun terhadap rakyatnya dan siap mengakomodir aspirasi mereka seluas-luasnya ketika tidak sejalan dengan kebijakannya, 3) Adolf Hitler (L. 1889 M) yang menggunakan cara-cara militeristik seperti menjalankan dua fungsi; militer dan nonmiliter dalam menjalankan tampuk kepemimpinannya sehingga menyebabkan kurangnya trust masyarakat dan membawa negara Jerman ke jurang instabilitas nasionalnya.

Pemerintah dan elemen masyarakat dalam mengemban tugasnya harus menjalankan prinsip penguatan nilai-nilai karakter pemimpin dan berusaha sekuat mungkin memegang prinsip ini sesuai dengan amanah yang diemban agar tercipta kualitas kepribadian anak bangsa yang bisa membawah negara ini ke arah perubahan yang lebih baik ke depannya.
\end{abstract}

Kata Kunci : Kepemimpinan, Nabi Musa AS, Pemerintah, Masyarakat 


\begin{abstract}
The conclusion of this dissertation is: leader character education in the story of Prophet Musa AS which includes a number of main characters, such as patient, visionary, competent, integrity, reformer, solutive, religious, credible, intelligent, good at working together (team work), strong determination, informant, learner and tawadhu '.

This dissertation has differences of opinion with: 1) Niccolo Machiavelli (L. 1469 M) which separates ethics and politics in implementing and applying the values of its leadership. The government as the institutional leader of the national leadership must carry out the duties of the state properly in accordance with the values of the nation's personality as stated in the 1945 Constitution and Pancasila, 2) Alexander the Great (L. 340 SM) whose ambition is to accumulate wealth, acting brutally, ordering his followers to worship him and not hesitate to slaughter anyone who opposed his authority. The government and all office holders actually live with the character of simplicity, polite towards their people and ready to accommodate their aspirations to the greatest extent when not in line with their policies, 3) Adolf Hitler (L. 1889 M) who used militaristic methods such as running two functions; military and non-military in carrying out their leadership, causing a lack of public trust and bringing the German state to the brink of its national instability.

The government and community elements in carrying out their duties must carry out the principle of strengthening the character's values of the leader and try their best to hold this principle in accordance with the mandate to create a quality personality for the nation that can lead to a better change in the future.
\end{abstract}

Keywords : Leadership, Moses Prophet, Government, Community 


\section{A. PENDAhuluan}

Maraknya ucapan/berita bohong atau apa yang disebut dengan berita atau informasi palsu (hoax), akhir-akhir ini menimbulkan masalah yang sungguh serius. Beberapa riset tentang akibat berita palsu yang dilakukan oleh Pew Research Center, ${ }^{1}$ Kemenkoinfo (2016), ${ }^{2}$ dan Kepolisian Republik Indonesia, ${ }^{3}$ menyebutkan bahwa penyebar kebohongan melalui media tertentu, merusak dan mencemarkan nama baik dan harga diri seseorang maka akan berurusan dengan hukum pidana.

Hal ini disinyalir dari akibat pemahaman yang kurang komprehensif tentang norma-norma sosial dan nilai-nilai keagamaan, minimnya pengetahuan atau pengenalan terhadap informasi yang beredar di tengah-tengah masyarakat. Seperti yang pernah terjadi pada beberapa pemimpin di dunia Barat, sehingga hal itu mengganggu proses demokrasi dan stabilitas negaranya. Sebuah informasi harian Kompas terbitan Senin 20 Juni 2011 tertulis tentang Kerusakan Mental Mencemaskan sebagai headline yang terpampang di halaman depan. ${ }^{4}$ Dalam berita tersebut disampaikan sebagai ikhtisar hal-hal yang terkait penyelenggara negara berupa fakta:

1. Sepanjang 2004-2011, Kementerian Dalam Negeri mencatat 158 kepala daerah yang terdiri atas gubernur, bupati dan walikota tersangkut korupsi.

2. Sedikitnya 42 anggota DPR terseret korupsi pada kurun waktu 2008-2011.

3. 30 anggota DPR periode 1999-2004 dari 4 parpol terlibat kasus dugaan suap pemilihan Deputi Gubernur Bank Indonesia.

4. Kasus korupsi terjadi di sejumlah institusi seperti KPU, Komisi Yudisial, KPPU, Ditjen Pajak, Bank Indonesia dan BKPM.

Terkait penegak hukum terungkap fakta bahwa:

${ }^{1}$ Di Amerika $23 \%$ orang dewasa terlibat dalam penyebaran berita palsu. $14 \%$ di antaranya bahkan menyebarkan informasi yang sejak awal mereka ketahui sebagai hoax. (Journalism.org)

2 Dalam "Kominfo Dorong Penggunaan Media Sosial untuk Pustakawan." dalam https://kominfo.go.id, 12 Oktober 2016. Diakses pada 14 Februari 2017.

3 Tempo, "Mabes Polri: Penyebar Hoax Diancam Hukuman 6 Tahun Penjara." Diakses pada Minggu, 20 November 2016, dalam http://m.tempo.co

${ }^{4}$ Muclash Samani dan Harianto, M.S, Konsep dan Model Pendidikan Karakter, Bandung, PT. Remaja Rosdakarya, 2011, cet.I, hal. 4. 
1. Sepanjang 2010 Mahkamah Agung menjatuhkan sanksi kepada 107 hakim, baik berupa pemberhentian maupun teguran. Jumlah tersebut meningkat dibandingkan dengan tahun sebelumnya yakni sebanyak 78 hakim.

2. Pegawai kejaksaan yang dijatuhi sanksi sepanjang 2010 mencapai 288 orang meningkat $60 \%$ dibandingkan tahun 2009 yang sebanyak 181 orang. Dari 288 orang pada tahun 2010 tersebut. 192 orang yang dijatuhi sanksi adalah jaksa.

3. Selama tahun 2010 sebanyak 294 polisi dipecat dari dinas Polri yang terdiri dari 18 perwira, 272 orang bintara dan 4 tamtama.

Kemudian informasi lain yang menunjukkan bahwa bangsa Indonesia sedang mengalami krisis moral saat ini, sebagaimana penulis kutip pada artikeldengan judul "Kepemimpinan Berkarakter Sebagai Model Pendidikan Karakter" karya Husaini Usman," disebutkan bahwa seorang profesor, sebagai dosen teladan dikampusnya sudah menjadi tersangka korupsi oleh KPK.

Pada sisi lain yang menjadi pemicu bangsa Indonesia saat ini mengalami kerusakan di berbagai macam bidang, umumnya disebabkan karena kurangnya pemahaman yang baik terhadap ajaran agama. Ditambah dengan sebuah informasi yang disampaikan oleh budayawan Mochtar Lubis, yang memberikan deskripsi karakter bangsa Indonesia yang sangat negatif. Dalam ceramahnya di Taman Ismail Marzuki, 6 April 1977, Mochtar Lubis mendeskripsikan ciri-ciri umum manusia Indonesia sebagai berikut: "Munafik, enggan bertanggungjawab, berjiwa feodal, masih percaya tahayul, lemah karakter, cenderung boros, suka jalan pintas, dan tidak suka bekerja keras."

\section{B. KARAKTER PEMIMPIN}

Dalam masyarakat Jepang ada sebuah ungkapan menarik yang mengandung banyak makna. Ganbatte Kudasai. Dari sekian makna yang ada, ungkapan ini mengandung unsur motivasi dan semangat untuk terus berjuang dan pantang menyerah. Seorang mahasiswa di depan profesornya, seorang karyawan di depan

5 Usman, Husaini, FT. Universitas Negeri Yogyakarta, Pada Jurnal Pendidikan Karakter, Tahun III, Nomor 3, Oktober 2013.

${ }^{6}$ Adian Husaini, Pendidikan Islam Membentuk Manusia Berkarakter dan Beradab, Jakarta: Adabi Press, 2012, cet. I, hal. 36-37. 
bosnya, atau siapapun yang menerima sebuah tugas, maka akan selalu mengatakan "Gambarimasu!" yang berarti akan berusaha dengan sebaik-baiknya.

Semangat pantang menyerah inilah yang kemudian membangun karakter bangsa Jepang yang tangguh, teliti, rajin dan pantang menyerah. Hasilnya adalah apa yang kita lihat sekarang di mana Jepang, sebuah negara satu-satunya di dunia yang pernah "menerima" bom atom dan porak-poranda akibat Perang Dunia II, bangkit kembali menjadi sebuah raksasa ekonomi dan tehnologi dunia. Tentu saja, prestasi yang dicapai oleh Jepang tidaklah semudah yang dikira. Mereka berusaha melalui proses yang panjang. Yang menarik adalah ketika semua proses mereka lalui dengan ketekunan dan kesabaran, bukan mencari jalan pintas untuk kesuksesan semu. Proses ini juga bukan tanpa halangan dan kegagalan, ${ }^{7}$ namun dengan ketekunan dan kesabaran, Jepang mampu menghadapi dan kemudian mengalahkan hambatan-hambatan seperti minimnya sumberdaya alam yang kemudian memacu bangsa Jepang untuk mencari alternatif penyelesaiannya dan hasilnya adalah inovasi tehnologi yang luar biasa.

Dengan keunikan yang demikian, lalu muncul pertanyaan, apakah karakter yang melekat ini sebagai representasi karakter semua orang Jepang? Clark (1979) mengatakan bahwa orang Jepang digambarkan sebagai masyarakat yang memiliki mentalitas kelompok, memiliki rasa malu yang tinggi, menganut gaya manajerial keluarga, jujur, tertib, bersih dan lain sebagainya. ${ }^{8}$ Karakter masyarakat Jepang terbentuk dipengaruhi aspek historis maupun sosio-kultural.

\section{1) Prinsip Bushido}

Bushido berasal dari kata bushi 'ksatria' dan dou 'jalan', sehingga secara keseluruhan dapat diartikan sebagai jalan ksatria. Bushidou merupakan sebuah aturan moral ksatria yang berlaku di kalangan samurai pada zaman feodal (abad 12-19). Pada masa itu, samurai sangat disegani masyarakat, terlebih pada zaman Tokugawa, saat diterapkannya politik sakoku (politik mengisolasi

7 Tonny Dian Efendi, pada makalah berjudul "Ganbatte Kudasai! Karakter Jepang yang Mensukseskan" ketika mengulas buku tersebut yang ditulis oleh A.A. Azhari, Penerbit: Grafindo, Cet. 1, Juni 2011.

${ }^{8}$ Elizabeth Ika Hesti Aprilian Nindia Rini, Karakteristik Masyarakat Jepang, Kiryoku, Volume 1, No 3, 2017, e-ISSN:, 2581-0960 p-ISSN: 25990497 
diri dari dunia luar). Saat itu secara resmi bushidou disusun dalam bentuk ketika yang diterapkan dan diajarkan pada masyarakat.

Prinsip bushidou erat kaitannya dengan ajaran Budha Zen, karena perkembangannya di Jepang terjadi pada masa yang hampir sama. Kepercayaan para samurai harmoni dengan alam semesta, khususnya dengan alam lingkungan. Harmoni diupayakan untuk memperoleh ketenangan, kesederhanaan dan keindahan. Dalam buku Bushidou dijelaskan pentingnya ajaran Zen mengenai kepercayaan pada takdir dan ketenangan hati yang ditempuh melalui meditasi bagi para samurai. ${ }^{9}$ Ajaran ini membuat samurai dapat bersikap tenang dan siap menjalani tugas yang diberikan tanpa rasa takut. Sikap berani yang didapat dari ketenangan hati ini merupakan salah satu prinsip bushidou yang utama. Sementara itu ajaran Shintou mengajarkan loyalitas pada pimpinan, penghormatan pada warisan leluhur dan sikap bakti. Kombinasi dua kepercayaan ini membentuk jiwa samurai yang tangguh. Aspek spiritual menjadi aspek penting dalam bushidou karena dengan penguasaan atas diri melalui pengendalian dirilah, kekuatan akan timbul sehingga samurai dapat menaklukkan lawan.

Nilai-nilai dalam ajaran bushidou nampak ketika terjadi perang antar daimyou yang terjadi sejak zaman kamakura sampai tahun 1600. Perang yang melibatkan banyak samurai ini menanamkan pula nilai-nilai kesetiaan, keberanian dan kehormatan dalam masyarakat Jepang. Kaum samurai berhasil memberi pengaruh pada kehidupan masyarakat Jepang dengan prinsip-prinsip yang menjiwai sikap mereka dalam kehidupan bermasyarakat.

Filosofi Bushido yang tertuang dalam semangat Gambaru inilah yang kemudian mewarnai kehidupan masyarakat Jepang sehari-hari. Hal ini menghasilkan sebuah masyarakat Jepang yang mandiri dan tangguh. Selain pantang menyerah dan kerja keras, semangat Gambaru menghasilkan budaya masyarakat Jepang yang haus akan ilmu pengetahuan. Orang Jepang di masa lampau belajar dari keberhasilan bangsa-bangsa lain, terutama bangsa Barat dan bertekad akan menyamainya. Oleh karena itu masa Restorasi Meiji merupakan salah satu tonggak penting dalam

${ }^{9}$ Nitobe, I. 1980. Bushidou: The Soul of Japan. Tokyo: Teibi Printing, seperti yang dikuti pada jurnal Kiryoku, Volume 1, No 3, 2017, e-ISSN:, 2581-0960 p-ISSN: 2599-0497 
perkembangan masyarakat Jepang. Setelah karakter bangsa Jepang telah terbentuk dengan filosofi bushido di masa samurai, hal ini kemudian diperkuat dengan keterbukaan dan modernisasi Jepang melalui Restorasi Meiji. Jepang menjadi negara pertama di Asia yang menerapkan prinsip demokrasi Barat dengan membentuk parlemen pada sistem politiknya. Semangat belajar ini kemudian diteruskan pasca Perang Dunia II, ketika masyarakat Jepang belajar keunggulan produk Barat dan kemudian meniru dan dikembangkan dengan inovasi mereka sehingga menghasilkan produk-produk yang mampu bersaing dengan produk Barat.

Prinsip bushidou mampu memberikan dampak dalam sejarah perkembangan masyarakat Jepang dari waktu ke waktu. Nilai-nilai dalam prinsip bushidou diajarkan para samurai dan tertanam dalam hati individu masyarakat Jepang. Aspek mental yang tertanam dalam hati masyarakat Jepang ini dianggap sangat berperan dalam pencapaian akhir dari setiap problematika kehidupan masyarakat Jepang.

Singkatnya bushidou memiliki tujuh kode etik yang menjadi nilai utama, yaitu sebagai berikut: Integritas $(G i),{ }^{10}$ keberanian $(\mathrm{Yu})$, welas asih (Jin), ${ }^{11}$ penghormatan $(\mathrm{Rei}),{ }^{12}$ kejujuran $\quad$ (Makoto $),{ }^{13}$ kehormatan $\quad$ (Meiyo $),{ }^{14}$ dan loyalitas/kesetiaan (Chuugi). ${ }^{15}$

${ }^{10} \mathrm{Gi}$ atau integritas berarti jujur dan utuh. Keutuhan yang dimaksud yakni keutuhan dari segala aspek kehidupan, terutama antara pikiran, perkataan, dan perbuatan.

${ }^{11}$ Yin mewakili sifat feminim yaitu mencintai. Meski berlatih ilmu pedang dan strategi berperang, para samurai harus memiliki sifat mencintai sesama, kasih sayang dan peduli.

${ }_{12}$ Rei atau penghormatan, yakni bahwa samurai tidak pernah bersikap kasar dan ceroboh, namun senantiasa menggunakan kode etiknya secara sempurna sepanjang waktu. Sikap santun dan hormat tidak saja ditujukkan pada pimpinan dan orangtua, namun kepada tamu atau siapapun yang ditemui. Sikap santun meliputi cara duduk, berbicara, bahkan dalam memperlakukan dan merawat benda ataupun senjata.

${ }^{13}$ Makoto atau kejujuran, yakni bersikap jujur dan tulus, berkata dan memberikan informasi yang sesuai dengan kenyataan dan kebenaran. Para ksatria harus menjaga ucapannya dan selalu waspada, tidak menggunjing, bahkan saat melihat atau mendengar hal-hal buruk tentang kolega.

14 Meiyo atau kehormatan, yakni menjaga kehormatan dengan menjalankan kode bushidou secara konsisten sepanjang waktu dan tidak menggunakan jalan yang amoral.

${ }^{15}$ Chuugi atau loyalitas ditunjukkan dengan dedikasi yang tinggi dalam melaksanakan tugas. Puncak kehormatan seorang samurai adalah mati dalam menjalankan tugas dan perjuangan. 


\section{2) Harmoni (wa)}

Dalam hubungan kemasyarakatannya, bangsa Jepang lebih mengutamakan interaksi sosial dan kebersamaan dalam kelompok. Hal ini terkait dengan nilai budaya harmoni ( $w a$ ) yang dianut dalam masyarakat. Dalam hidup bermasyarakat, masyarakat Jepang sangat memperhatikan chouwa, yaitu keselarasan, keseimbangan, keserasian, harmoni dan keharmonisan dalam masyarakat.

Sikap memaksakan pendapat sendiri tanpa memperhatikan kondisi sekitar, dianggap sebagai wa o toosu 'memaksakan individualitas' yang tidak disukai dalam kehidupan bermasyarakat. Orang Jepang percaya bahwa harmoni antara anggota masyarakat sangat penting dan diperlukan dalam membangun stabilitas dalam masyarakat. Masyarakat Jepang sering disebut sebagai masyarakat yang berorientasi kolektif atau group oriented society. Sebagai contoh sikap menjaga harmoni dalam kehidupan bermasyarakat adalah penggunaan kata hai 'ya' maupun iie 'ya' yang biasanya merupakan tanda pembicara berpendapat sama/tidak saja dengan lawan bicara, namun di Jepang kata ini tidak bisa dijadikan patokan apakah yang bersangkutan setuju atau tidak dengan pendapat lawan bicaranya. Orang Jepang adalah sosok yang menentukan sikap individu dengan menyesuaikan perasaan lawan bicara, sikap menjaga wa seperti demikian memeriksa secara detail situasi dan memantau perasaan lawan bicara, mempertimbangkan posisi lawan bicara, untuk menjaga harmoni.

Identitas 'kelompok' tidak hanya merujuk pada kelompok yang terbentuk karena hubungan darah, namun juga karena ikatan secara geografis dan hubungan pekerjaan, seperti dalam perusahaan. Keterikatan hubungan individu dalam kelompok menuntut loyalitas dan komitmen yang kuat dari pada anggotanya. Sebuah kebanggaan yang diperoleh individu akan dianggap sebagai kebanggaan kelompok dan sebaliknya sebuah aib yang menimpa seorang anggotanya akan menjadi aib bagi kelompok tersebut. Menjaga reputasi ( $k a o$ ) juga menjadi satu hal penting dalam hal ini.

3) Konsep Uchi Soto

Kesadaran sebagai anggota dalam kelompok yang kuat menjadi latar munculnya konsep uchi soto. Konsep uchi soto ini 
membagi kelompok berdasarkan 3 hal. ${ }^{16}$ Hal-hal tersebut menentukan sikap dan ragam bahasa yang digunakan oleh orang Jepang.

\section{4) Omoiyari, Amae, On, Gimu, Giri dan Ninjou}

Sikap keterikatan, komitmen serta loyalitas sebagian masyarakat dengan kesadaran kelompok, tidak terlepas dari tata nilai dan norma budaya Omoiyari, ${ }^{17}$ Amae, ${ }^{18}$ On, ${ }^{19}$ Gimu, ${ }^{20}$ Giri, ${ }^{21}$ dan Ninjou. ${ }^{22}$

5) Aimai hyougen.

Aimai hyougen adalah pengungkapan maksud pembicara secara samar-samar. Masyarakat Jepang acapkali menggunakan ungkapan tidak langsung (enkyoku) dalam mengemukakan maksudnya. Bahkan tidak hanya ungkapan tidak langsung saja, melainkan ada juga yang mengungkapkan hal berkebalikan

${ }^{16}$ Yaitu: 1) apakah seseorang merupakan anggota kelompok tertentu atau bukan, 2) baru pertama kali bertemu atau sudah lama kenal, atau 3) apakah orang tersebut secara usia dan kepangkatan berada di atas atau bawah pembicara.

17 Omoiyari mengacu pada sikap empati dan ketulusan tanpa mengharapkan balasan dari pihak penerima. Omoiyari ditunjukkan dengan kemampuan untuk merasakan apa yang dirasakan orang lain. omoiyari bisa berarti membantu mewujudkan mimpi dan keinginan orang lain. Bagi masyarakat Jepang Omoiyari merupakan apa yang dibutuhkan orang lain (loyal) dan mencegah perbuatan yang dapat merugikan orang lain.

18 Amae berarti sikap ketergantungan terhadap orang lain. Hal ini berhubungan dengan konsep omoiyari karena dalam pemikiran masyarakat Jepang seseorang yang melakukan omoiyari memerlukan orang yang bergantung kepadanya, demikian pula sebaliknya. Pengertian konsep amae mempunyai sikap menganggap orang lain selalu memiliki niat baik dan tulus, sehingga akan selalu siap membantu kapan saja dibutuhkan.

${ }^{19}$ On adalah beban, hutang, atau suatu berkat/bantuan yang kita terima dari orang lain. pengertian on ini tidak hanya pada kewajiban membalas budi, namun juga mempunyai makna cinta kasih, kesetiaan dan keramahan. On menunjukkan nilai moralitas masyarakat Jepang yang sangat tinggi akan kesetiaan, ketulusan dan pengabdian.

${ }^{20}$ Gimu adalah kewajiban seseorang untuk membayar kembali apa yang telah diterima. Gimu dalam sistem nilai budaya Jepang mengacu pada pembayaran kewajiban yang tidak memiliki batasan waktu sehingga adakalanya gimu dirasa tidak pernah mencukupi walalupun dilakukan seumur hidup.

Giri adalah jenis lain dari kewajiban untuk pemenuhan on lainnya. Ia mempunyai batasan waktu pembayaran. Hutang dan beban yang diterima dari orang lain wajib dibayar dengan jumlah yang sama.

${ }^{22}$ Ninjou merujuk pada perasaan universal manusia terhadap manusia lainnya seperti rasa cinta, perhatian, belas kasih, simpati, kesedihan dan perasaan alami selayaknya terhadap orangtua, anak dan kekasih. 
dengan harapan lawan bicara memahami maksud sebenarnya. Komunikasi seperti ini membutuhkan rasa saling pengertian satu sama lain.

\section{ANALISIS TEORITIS KARAKTER PEMIMPIN}

Perkembangan teori kepemimpinan selama lima dekade terakhir sangat pesat. Banyak penelitian dilakukan untuk mengembangkan teori ini, baik penelitian dengan proses penalaran deduktif maupun proses penalaran induktif. Studi yang didasarkan pada penalaran deduktif (deductive reasoning) dimaksudkan untuk melihat bagaimana keefektifan suatu teori kepemimpinan dalam aplikasinya. Artinya perkembangan kepemimpinan berangkat dari kajian teori yang sudah ada. Sedang studi yang didasarkan pada penalaran induktif (inductive reasoning) lebih mendalam sebuah teori kepemimpinan terkait dengan pengayaan variabel-variabelnya. Hal ini karena proses penalaran induktif berangkat dari kajian fenomena yang terjadi di lingkungan masyarakat.

Perkembangan teori kepemimpinan seperti halnya perkembangan teori-teori lain tidak bisa lepas dari filsafat ilmu yang mendasarinya. Seperti kita ketahui bersama bahwa semua ilmu pengetahuan dilahirkan dari rahim filsafat, sehingga bisa dikatakan filsafat adalah induk dari semua cabang ilmu pengetahuan. $^{24}$

Teori kepemimpinan (leadership theory) mulai berkembang pada abad ke-19. Perkembangan teori kepemimpinan secara evolutif mulai dimaksudkan untuk menggali lebih jauh dari Great Man Theory, Traits Theory, Situational Theory, Behaviour Theory, Contigency Theory, Path Goal Theory sampai dengan Transactional dan Transformational Theory dan terakhir dari perkembangan konsep kepemimpinan adalah kepemimpinan spiritual. ${ }^{25}$

${ }^{23}$ Dalam arti perkembangan suatu teori kepemimpinan berangkat dari kajian teori yang sudah ada. Lihat: Hening Riyadiningsih, Teori Kepemimpinan: Sebuah Tinjauan Dari Perspektif Filsafat Ilmu, Volume 12, No.1 Januari 2016 -SEGMEN Jurnal Manajemen dan Bisnis, Universitas Wijaya Kusuma, hal. 1.

${ }^{24}$ Hening Riyadiningsih, Teori Kepemimpinan: Sebuah Tinjauan Dari Perspektif Filsafat Ilmu, Volume 12, No.1 Januari 2016 -SEGMEN Jurnal Manajemen dan Bisnis, Universitas Wijaya Kusuma, hal. 2

${ }^{25}$ ICRO, Iran the Cradle of Civilization, cet I, Jakarta, Kedutaan Besar Republik Iran, 2009, hal.16. 
Kepemimpinan sebagai sebuah teori dibangun dengan asumsi dasar "terdapat cara-cara tertentu dalam mempengaruhi orang untuk mencapai tujuan bersama." Berdasarkan asumsi tersebut maka obyek yang harus dipelajari dalam teori tersebut dapat dikembangkan. Seperti telah disebutkan di atas dalam filsafat ilmu, objek ilmu meliputi obyek material (obyek benda yang dipelajari) dan obyek formal (dimensi yang mana dari benda tersebut yang dipelajari/dimensi ilmu) ${ }^{26}$

Obyek material teori kepemimpinan adalah "pengaruh seseorang terhadap orang lain" mungkin dua orang atau lebih dalam pola interaksi tertentu. Selanjutnya masing-masing pengemuka teori kepemimpinan mengkaji teori tersebut dari obyek formal yang berbeda-beda terhadap obyek material yang sama yaitu "pengaruh seseorang terhadap orang lain." Dengan demikian, berkembang ragam teori kepemimpinan sesuai dengan cara pandang masing-masing ilmu penopang.

Terdapat banyak teori kepemimpinan, yaitu mulai dari Great Man Theory, Traits Theory, Situational Theory, Behaviour Theory, Contigency Theory, Path Goal Theory sampai dengan Transactional dan Transformational Theory, yang bila merujuk pada pendapat Mustopadidjaja ${ }^{27}$ bahwa aliran teori kepemimpinan itu hanya ada tiga yaitu aliran genetis, aliran sosial, dan aliran ekologis. Aliran sosial melihat kepemimpinan dari sudut pandang genetika, aliran sosial mengelompokkan teori kepemimpinan dari sudut pandang situasional, sedangkan aliran ekologis merupakan aliran teori kepemimpinan dari sudut pandang gabungan genetika atau personal dan situasional.

Berbagai cara pandang tersebut menunjukkan keberagaman obyek formal investigasi ilmuwan, dengan sudut pandang yang berbeda terhadap obyek material yang sama, yakni pengaruh seseorang terhadap orang lain.

Selain hal tersebut di atas terdapat sudut pandang terhadap perkembangan teori kepemimpinan dari mode eksistensi

${ }^{26}$ Salam Soeprapto, 2002a, Metode Ilmiah dalam Filsafat Ilmu sebagai dasar Pengembangan Ilmu Pengetahuan, Yogyakarta, Liberty dan Siswanto, 2010, Ilmu Manajemen Preskriptif Vs Deskriptif, Suatu Tinjauan dari Perspektif Filsafat Ilmu, Jurnal Masyarakat Kebudayaan dan Politik, Volume 21, No. 2: 193-202.

${ }^{27}$ Mustopadidjaja, Beberapa Dimensi dan Dinamika Kepemimpinan Abad 21, http://scribd.com/doc/11491115/Dimensi-Dinamika-KEPIM-ABAD21.Pdf file. 
Kierkegaard. ${ }^{28}$ Kierkegaard membagi mode eksistensi menjadi tiga yaitu mode eksistensi estetika, mode etika, dan religi. Berdasarkan mode eksistensi tersebut, ragam teori kepemimpinan yang ada dikelompokkan dalam tiga posisi yaitu instrumental, responsibilitas, dan spiritual. Secara ontologi, posisi kepemimpinan instrumental didasarkan pada sudut pandang mekanikal, semua bagian dalam organisasi secara eksternal saling berhubungan dan bersifat deterministik.

Posisi kepemimpinan responsibilitas secara ontologi, didasarkan pada sudut pandang budaya. Artinya, setiap orang dalam organisasi mempunyai keyakinan, nilai, norma, sikap dan keahlian tertentu. Dalam posisi ini ${ }^{29}$ pemimpin dituntut untuk bisa memahami budaya orang-orang yang ada dalam suatu organisasi. $^{30}$ Dalam posisi teori kepemimpinan spiritual didasarkan pada sudut pandang organik, di mana semua bagian dalam organisasi saling berhubungan, saling membutuhkan satu dengan yang lain membentuk suatu pola tertentu. ${ }^{31}$

\section{KONSEP KARAKTER KEPEMIMPINAN NABI MUSA AS DALAM AL-QUR'AN}

Term Al-Qur'an yang Berhubungan dengan Karakter Kepemimpinan Nabi Musa AS

1. Kisah Nabi Musa AS dengan Fir'aun.

${ }^{28}$ Stornletten, Vivi.M.L, \& Jacobsen, Ove.D., Development of Leadership Theory in The Perspective of Kierkegaard's Philosophy, Journal of Business Ethics, 2014

${ }_{29}$ Menurut Plato, para pemimpin diambil di antara para "penjaga", dari mereka yang mendalami filsafat. Itulah paham masyhur Plato tentang "rajafilosof". Filosof adalah orang yang sanggup untuk melihat idea-idea atau hakikat-hakikat rohani di belakang bayang-bayang alam indrawi berubahubah. Hal itu mungkin karena ia telah mengatasi keterikatan pada nafsu dan indra dan dengan demikian bebas dari pamrih. Seorang filosof dapat memimpin masyarakat dengan berorientasi pada idea metafisik tertinggi, idea kebaikan. (Suseno Franz Magnis (2003), Etika Politik, Prinsip-prinsip Moral Dasar Kenegaraan Modern, Jakarta: Gramedia), sebagaimana yang dikutip M.Alfan Alfian, pada bukunya "Wawasan Kepemimpinan Politik, Perbincangan Kepemimpinan di Bawah Kekuasaan."hal.65-66, cet-1, 2018, Penerbit: Penjuru Ilmu.

${ }^{30}$ Stornletten, Vivi.M.L, \& Jacobsen, Ove.D., Development of Leadership Theory in The Perspective of Kierkegaard's Philosophy, Journal of Business Ethics, 2014.

${ }^{31}$ Ajid Thohir, Studi Kawasan Dunia Islam, cet I, Jakarta: Rajawali Press, 2009, hal. 188. Lihat pula ICRO, Iran the Cradle of Civilization, cet I, Jakarta, Kedutaan Besar Republik Iran, 2009, hal.5. 


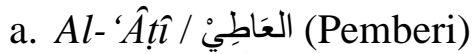

Term Al-'Ațî ini disebutkan di dalam surah Thaha, pada firman Allah SWT yang berbunyi:

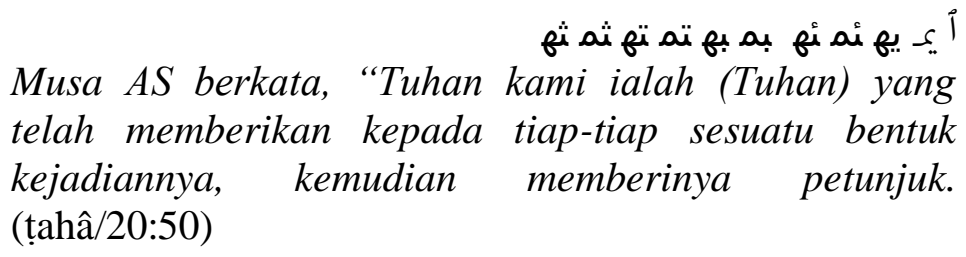

Ayat ini merupakan penggalan dari kisah dialog antara Nabi Musa AS dan Fir'aun. ${ }^{32}$ Allah menceritakan dalam firmanNya ini tentang Fir'aun, bahwasanya dia bertanya kepada Musa AS dengan mengingkari sang Pencipta, Rabb sekaligus

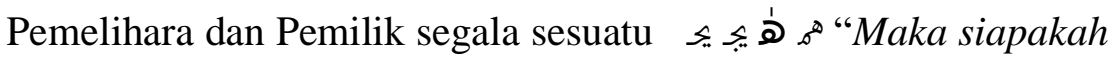
Rabbmu berdua, hai Musa?" Yakni, yang telah mengutus dan mengirimmu? Aku tidak mengenalnya, dan setahuku, tidak ada ilâh lain bagimu selain-Aku?" "Musa AS menjawab: "Rabb kami ialah (Rabb) yang telah memberikan kepada tiap-tiap sesuatu bentuk kejadiannya.." Ali bin Abi Thalhah menceritakan dari Ibnu Abbas, dia mengatakan: "Dia telah menciptakan pasangan bagi segala sesuatu." Adh-Dhahhak mengatakan dari Ibnu Abbas: "Dia telah menjadikan manusia sebagai manusia, keledai sebagai keledai, dan kambing sebagai kambing." Said bin Jubair mengatakan: "Dia berikan kepada setiap makhluk apa yang dibutuhkan bagi penciptaannya, da Dia tidak menerapkan ciptaan manusia pada binatang, demikian juga binatang pada manusia, tidak juga memberlakukan ciptaan kambing pada anjing dan tidak juga ciptaan anjing pada kambing. Jadi, Dia berikan segala sesuatu yang memang dibutuhkannya, berupa perkawinan dengan menyediakan segala sesuatu untuk itu, tidak ada sesuatu pun dari-

${ }^{32}$ Di sini terjadi perdebatan, pembahasan dan percakapan panjang lebar antara Nabi Musa dengan Fir'aun. Ketika Nabi Musa kembali dari pengasingan dan menghadap Fir'aun, Fir'aun mempertanyakan, seperti yang tersebut dalam surah as-Syu'ara/26: 19-21. Setelah membicarakan perihal tauhid ini Fir'aun mengatakan bahwa Nabi Musa adalah orang gila. Saat itu Nabi Musa ingin menunjukkan bukti, namun Fir'aun meragukannya. Kemudian terjadikan peristiwa tongkat dengan ahli sihir. Lihat: Afareez Abd Razak Al-Hafiz, Misteri Fir'aun Musuh Para Nabi, Menyingkap Tabir Peradaban Paling Perpengaruh Sepanjang Zaman, cet-2, Desember 2012, Penerbit: Zaytuna, hal. 247. 
Nya yang serupa dalam hal perbuatan, baik itu berupa penciptaan, pemberikan rizki, maupun perkawinan., 33

Pada ayat-ayat yang lalu Allah SWT menghibur Musa AS dan Harun AS supaya keduanya jangan takut berdakwah menghadapi Fir'aun, ${ }^{34}$ karena Allah SWT yang selalu menjaganya, dan supaya keduanya pergi menemui Fir'aun tanpa ragu-ragu, pada ayat ke-50 ini menerangkan bahwa setelah Musa AS dan Harun AS melaksanakan perintah Allah SWT dan setelah keduanya tiba di depan istana Fir'aun, terjadilah tanya jawab antara mereka seputar Tuhan Musa, tugasnya sebagai pemberi karunia dan rahmat kepada manusia. Di ayat ke-50 ini Allah SWT menerangkan jawaban Musa AS atas pertanyaan Fir'aun bahwa yang mengutus keduanya ialah Tuhan yang telah melengkapi makhluk yang diciptakannya dengan anggota tubuh sesuai dengan kepentingannya masing-masing. ${ }^{35}$ Sebagian ahli tafsir mengatakan: Dia telah memberikan bentuk ciptaan kepada segala sesuatu, kemudian memberinya petunjuk. Hal itu sama seperti firman-Nya dalam surah Al-A'laa [87]: 3 yang berbunyi: "Dan yang menentukan kadar (masing-masing) dan memberi petunjuk." 36

Dalam tafsir fì Zilâl al-Qur'ân, Sayyid Quthb memaparkan ilustrasi kedatangan Musa AS dan Harun ke raja Fir'aun. Mereka berdua mendatangi Fir'aun, meskipun redaksi ayat tidak menjelaskan bagaimana caranya mereka sampai kepada Fir'aun. Mereka berdua datang dalam keadaan disertai oleh Allah SWT, sambil mendengarkan dan memantau. Kekuatan apa yang mendorong Musa AS dan Harun AS untuk mampu berbicara di hadapan Fir'aun dengan segala karakternya? Mereka

${ }^{33}$ Abdullâh bin Muhammad bin Abdurrahmân bin Ishâq al-Sheikh, Tafsîr Ibnu Katsîr, cet-4 Muharram 1426 H/Februari 2005, Penerbit: Pustaka Imam Syafi'i, terjemahan dari judul asli Lubâbut Tafsîr Min Ibni Katsîr, Penerbit: Muassasah Dâr al-Hilâl Kairo, cet-1, Th. 1414 H/1994 M.

${ }^{34}$ Yakni Qs Thâhâ [20]: 42-48.

35 Kementerian Agama RI Direktorat Jenderal Bimbingan Masyarakat Islam Direktorat Urusan Agama Islam dan Pembinaan Syariah, Tahun 2012, Al-Qur'ân dan Tafsirnya, Jilid ke-6, juz 16-17-18, hal.148, dicetak oleh PT. Sinergi Pustaka Indonesia.

${ }^{36}$ Abdullâh bin Muhammad bin Abdurrahmân bin Ishâq al-Sheikh, Tafsîr Ibnu Katsîr, cet-4 Muharram 1426 H/Februari 2005, Penerbit: Pustaka Imam Syafi'i, terjemahan dari judul asli Lubâbut Tafsîr Min Ibni Katsîr, Penerbit: Muassasah Dâr al-Hilâl Kairo, cet-1, Th. 1414 H/1994 M. 
telah mampu menyampaikan semua yang diperintahkan oleh Tuhan mereka. ${ }^{37}$

Musa AS menjawab dengan menyebut sifat Allah SWT Yang Maha Pencipta, Maha Menumbuhkan dan Maha Mengatur, "Musa AS berkata, 'Tuhan kami ialah (Tuhan) yang telah memberikan kepada tiap-tiap sesuatu bentuk kejadiannya, kemudian memberinya petunjuk." Tuhan kami adalah Yang menganugerahkan eksistensi segala makhluk dalam bentuk yang telah diciptakan-Nya. ${ }^{38}$ Setelah Nabi Musa AS menjawab pertanyaan Fir'aun, iapun menganggap remeh Fir'aun dan mengingkari penuhanan dirinya. Dan setelah Fir'aun mendengarkan penjelasan Musa AS bahwasanya dirinya adalah utusan dari Alllah, Tuhan semesta alam, Fir'aun pun menanyakan kepadanya tentang Tuhan Musa AS (Thaha: 49-55).

Wahbah Zuhailî dalam tafsirnya At-Tafsîr al-Munîr, menguraikan secara lebih detail dari pendekatan lughawi

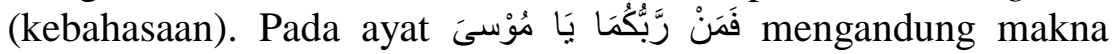
pertanyaan dari Fir'aun (Siapakah Tuhanmu hai Musa). Jika diperhatikan konteks ayatnya, pertanyaan ini diajukan Fir'aun kepada Musa, padahal saat itu Musa AS sedang berdua bersama Harun. Di sini Wahbah menjelaskan bahwa asalnya Nabi Musa AS adalah aktor utama rival Fir'aun. Sementara Nabi Harun hanya sebagai pendampingnya saja. ${ }^{39}$

Sampai di sini penulis mengamati bahwa, secara implisit ada sebuah sikap organisasi sosial dalam skup yang kecil namun memiliki pengaruh psikologis luar biasa. Secara psiko-analisis, Nabi Musa AS menganggap Harun AS adalah bagian dari pihaknya yang berhak mendapatkan posisi kebersamaan dengan Tuhannya. Itulah mengapa Nabi Musa AS menjawab pertanyaan Fir'aun dengan jawaban قَّالَ رَبْنَّا (Musa AS berkata, "Tuhan kami...”), bukan قَالَ رَبِّي (Musa AS berkata, "Tuhanku..”

\section{E. IMPLEMENTASI KARAKTER PEMIMPIN}

Melalui pendidikan karakter ini akan didapat dihasilkan kader-kader pemimpin bangsa yang memiliki komitmen yang kuat untuk memajukan bangsa dan negara, memiliki identitas

${ }^{37}$ Sayyid Quthb, Tafsîr Fî Zhilâl al-Qur'ân, juz XVI: Akhir Al-Kahfi, Maryam, dan Thâhâ, T.th , hal.406.

${ }^{38}$ Sayyid Quthb, Tafsîr Fî Zhilâl al-Qur'ân, juz XVI: Akhir Al-Kahfi, Maryam, dan Thâhâ, T.th , hal.406.

${ }^{39}$ Wahbah Zuhailî, Tafsîr al-Munîr, cet X, juz 8, Tahun 1430 H/2009 M, Dâr Fikr, Damaskus, Barâmikah, hal. 571. 
yang jelas, dan tidak terbawa arus globalisasi yang cenderung lebih mengutamakan hal-hal yang bersifat jangka pendek, hedonistik, individualistik, dan materialistik. Implementasi karakter kepemimpinan antara lain didasarkan pada nilai-nilai yang terkandung dalam Pancasila, Undang-undang Dasar 1945, semangat Sumpah Pemuda, pandangan dan pemikiran para pemimpin bangsa yang kredibel, nilai-nilai yang tumbuh dan berkembang di berbagai kepulauan di Indonesia.

Implementasi karakter kepemimpinan saat ini berada dalam keadaan yang kurang kondusif bahkan dalam keadaan kritis. Merajalela dan membudayanya berbagai macam tindakan korupsi, konflik horisontal, tawuran antara pelajar, radikalisme, terorisme, peredaran dan penggunaan narkoba, perusakan lingkungan, dan prostitusi, menunjukkan masih belum berjalannya implementasi pendidikan karakter pemimpin di institusi pendidikan secara efektif.

Apabila mem-flashback peran Kementerian Agama dalam pengembangan pendidikan Islam, terlihat begitu jelas bahwa pada tahun 1946 Kementerian Agama mulai mengembangkan perannya sebagai Pembina Pendidikan Agama di sekolah, madrasah dan perguruan tinggi berbasis Islam. ${ }^{40}$ Inilah sebuah implementasi dari tugas-tugas salah satu direktorat pembinaan pendidikan Islam. ${ }^{41}$

Guna mendukung implementasi karakter kepemimpinan di semua institusi ini, maka diperlukan hal-hal sebagai berikut: Pertama, menerapkan pendekatan belajar mengajar yang humanistik emansipatoris; ${ }^{42}$ Kedua, memperbaiki karakter sekolah atau pendidikan tinggi; Ketiga, menerapkan pendidikan demokrasi di sekolah atau perguruan tinggi. Keempat, menerapkan pendidikan multikultural di institusi pendidikan, dan Kelima, menciptakan budaya institusi yang mengarah pada

${ }^{40}$ Karel A. Steenbrink, Beberapa Aspek Islam di Indonesia Abad ke-19, Jakarta, Bulan Bintang, 1984, hal. 50.

${ }^{41}$ Yang setelah dimekarkan menjadi; (a) Direktorat Pendidikan Agama, (b) Direktorat Perguruan Tinggi Agama, di samping ada dua direktorat, yaitu Direktorat Pembinaan Pendidikan Agama Islam dan Direktorat Pembinaan Pendidikan Tinggi Agama Islam. Lihat: A. Hasymi, Mengapa Umat Islam Mempertahankan Pendidikan Agama dalam Sistem Pendidikan Nasional, Jakarta: Bulan Bintang, t.th, hal. 53.

${ }^{42}$ Yakni metode dan pendekatan yang lebih menekankan pada pemberian contoh (modeling), refleksi, problem solving, pengembangan wawasan, dan penilaian yang objektif. 
dihasilkannya manusia yang unggul (great person) baik secara fisik, intelektual, moral, emosional, sosial dan spiritual yang didasarkan pada nilai-nilai budaya bangsa.

\section{F. PENUTUP}

Karakter kepemimpinan Nabi Musa AS dalam perspektif Al-Qur'an yang dibahas pada disertasi ini dapat disimpulkan sebagai berikut:

Pertama, bahwa upaya implementasi karakter kepemimpinan dan problematikanya diharapkan dapat menjadi pegangan setiap generasi mendatang dan memberikan sebuah pemikiran baru terhadap perkembangan konsep karakter ideal dari kisah Nabi Musa AS menurut perspektif Al-Qur'an. Pemerintah, ulama, para tokoh, psikolog, teolog, sosiolog, dan pendidik serta masyarakat luas diharapkan dapat duduk bersama bersinergi sebagai upaya melaksanakan penerapan karakter pemimpin di semua level pemerintahan, swasta dan umum, dengan cara membangun kesadaran religius, kekuatan mental, menggalang kebersamaan dan mengasah kecakapan emosional dan intelektualitas.

Kedua, upaya penerapan karakter kepemimpinan Nabi Musa AS seperti karakter sabar, visioner, kredibel, kompeten dan pembelajar dapat menjadi acuan dalam mengimplementasikan karakter pemimpin di Indonesia. Konsep pembangunan karakter, kesabaran dalam pembinaan, dan kekokohan dalam proses kaderisasi kepemimpinan, dilandasi kesadaran religius sangat ditekankan dan dilakukan dengan serius. Dukungan penuh pemerintah dalam upaya melaksanakan pemimpin yang berkarakter menjadi patokan keberhasilan pemerintah dalam membentuk calon pemimpin yang diharapkan bersama.

Ketiga, upaya implementasi karakter pemimpin berangkat dari konsep yang telah dirumuskan dapat dilakukan sebagai berikut: a) penerapan nilai-nilai karakter pemimpin sebagai individu, b) penerapan nilai-nilai karakter pemimpin sebagai suami, istri, dan terhadap anak dalam lingkup keluarga, c) penerapan nilai-nilai karakter pemimpin sebagai individu di organisasi kemasyarakatan, mencakup rukun tetangga (RT), warga sekitar, masjid dan jamaahnya, ormas-ormas, LSM-LSM dan komunitas-komunitas lain yang ada dalam masyarakat, dan d) penerapan nilai-nilai karakter sebagai pelayan publik di 
lingkungan instansi-instansi pemerintahan, pelayanan publik, pendidikan, umum dan swasta.

Keempat, konsep karakter pemimpin yang telah ada saat ini seyogyanya dapat terus tingkatkan dan dikembangkan. Perlu pemetaan tentang generasi terbaik yang perlu diperhatikan agar kaderisasi kepemimpinan berjalan efektif dan memberikan perubahan bangsa secara optimal. Indonesia adalah negara yang religus sekaligus penuh prestasi. Oleh sebab itu sistem pendidikan yang dibuat sejatinya dibentuk untuk mengaktualisasikan nilai-nilai agama yang dijunjung tinggi guna melahirkan para pemimpin terbaik dan berkarakter.

Disertasi ini mendukung konsep dan sistem penerapan kepemimpinan yang digalakkan pada semua elemen dan instansi sosial dengan perangkat masing-masing sebagai solusi terhadap persoalan kepemimpinan bangsa. Al-Qur'an mendeskripsikan tentang konsep kepemimpinan (leadership) sebagai salah satu modal dan potensi terwujudnya karakter kepemimpinan yang bermuara pada sosok yang holistik, yakni kepribadian Nabi Musa AS.

Oleh sebab, penerapan karakter kepemimpinan Nabi Musa AS ini dapat dipahami dalam arti, mengaktualisasikan nilai-nilai kepemimpinan Nabi Musa AS secara integral pada semua aspek kehidupan manusia, baik itu perannya sebagai seorang individu, keluarga, masyarakat, organisasi masyarakat, maupun pelayanan publik dan pemerintah.

\section{DAFTAR PUSTAKA}

Abbasi, M.H, Shiddiqi, A., dan Azim, R.A. 20011, "Role of Effective Communications for Enchancing Leadership and Enterpreneurial Skill in University Students" dalam International Journal of Business ans Social Science Vol.2 No.10/Juni 2011, hlm.242-250.

Adizes, Ichak, How To Solve the Management Crisis. Los Angeles, MOOR, Inc., 1980.

Adrian, Furnham, David Pendleton, Leadership: All You Need To Know, First published 2012 by Palgrave Macmillan, ISBN 978-0-230-31945-5. 
Alexander, D.M. tt. Feraming Leadership Communication: Consequences for Organizational Leaders Resulting from Communication Failure: Ab Australian Case Study. Bathurst: Charles Sturt University.

Allen, Louis A., The Management Profession, New York, McGraw-Hill, 1964.

American Association of School Librarians, Empowering Leadership, Developing Behaviors for Success, Chicago. Illinois 60611-2795, 2013, ISBN: 978-0-8389-8657-8.

Anderson, Richard G, Management Strategis, New York, McGraw-Hill, 1965.

Andrew Marshall, Mathew Horsman, After The Nation-State Citizen, Tribalism and the New World Disorder, London: Harper Colins Publishers, 1994.

Appleby, Paul H, Public Administration for a Welfare State. London, Asia Publishing House, 1970.

Aram, John D, Dilemmas of Administration Behavior, Englewwod Cliffs, New Jersey, Prentice-Hall, 1976.

Arlestig, H.2008. Communication between Principals and Teacher s in Succesful Scholl, Umea: Faculty of Social Sciences, Umea University.

Arne Jessen, Svein, Project Leadership - Step by Step, Part I, 2nd edtion@2012 Svein Arne Jessen \& Bookboon.com, ISBN 978-87-7681-553-0.

Arthur James, Education With Character, The Moral economy of schooling, RoutledgeFalmer, Taylor \& Francis Group, London And New York, thn. 2003.

Ashgate, Regional Leadership in The Global System Ideas, Interest and Strategies of Regional Powers, edited by Daniel Flames, GIGA German Institute of Global and Area Studies, @Daniel Flames 2010, Ashgate Publishing Limited. 
Adair, J. 2007, Leadership For Innovation How to Organize Team Creativity and Leadership Ideas, London: Kogan Page Limited. , 2009. Develop Your Leadership Skill. London: Kogan Page Limited.

Anderson, B.I., 1993, "The Stage of Systemic Change dalam Inventing New System", Vol 51/No.1 September 1993, hlm.14-17.

2009, Advocacy Leadership Toward a PostReform Agenda in Education. New York: Routledge.

Albers, Henry H.,: Management: The Basic Concepts, New York, John Wiley, 1972.

, Principles of Management: A Modern Approach. New York, John Wiley, 1974.

Argyis, Chris, Executive Leadership: An Appraisal of a Manager in Action, New York, Herper, 1953.

, Personality and Organizations, New York, Harper, 1957.

, Leadership and Interpersonal Behavior, New York, Holt, 1961. 